\title{
3. HEMITURBIDITE: A NEW TYPE OF DEEP-WATER SEDIMENT ${ }^{1}$
}

\author{
Dorrik A. V. Stow ${ }^{2.3}$ and Andreas Wetzel ${ }^{4.5}$
}

\begin{abstract}
Cores recovered from the top kilometer of section on the distal Bengal Fan are dominated by fine-grained turbidites interbedded with thin pelagites and a distinctive sediment type showing characteristics intermediate between mud turbidites and pelagites. The particular properties of this facies include (a) thick bipartite beds comprising a thin basal zone of turbidite mud overlain by a thick bioturbated mud; (b) a bioturbated mud (which may occur without the basal zone) that shows burrowing continuous with sedimentation; and (c) slight grading of color, grain size, and geotechnical properties that continues even through the bioturbated part of the depositional unit. We infer that such beds were deposited slowly from an essentially stationary dilute suspension cloud that is formed directly from, but beyond and above, the dying stages of a large low-concentration turbidity current. Estimates of sedimentation rates indicate deposition over a period of a few weeks to a few months for a unit I $\mathrm{m}$ thick. We introduce the name hemiturbidite for this type of sediment, which is probably commonplace in most distal turbidite settings.
\end{abstract}

\section{INTRODUCTION}

Three sites $(717,718$ and 719$)$ were drilled on the distal Bengal Fan in the central Indian Ocean during Leg 116 of the Ocean Drilling Program (Fig. 1). The sediments recovered at all three closely spaced sites were dominated by silty, muddy, and bioclastic turbidites, with thin interbedded pelagic and hemipelagic intervals. The nature and distribution of these facies are described in detail elsewhere in this volume. However, in association with the more normal turbidites and pelagites encountered, there was a rather unusual facies that does not fit readily into any pre-existing deep-water sediment type. The purpose of this paper is to describe this facies in detail and to discuss the probable processes responsible for its deposition. We refer to the sediment initially as "Facies 7," following its designation in the facies paper (this Volume) and in Cochran, Stow, et al. (1989). Subsequently we propose "hemiturbidite" as a new name for this facies type.

\section{METHODS}

Standard visual observations were made of split cores, followed by X-rays of selected thin slabs, using the shipboard X-ray unit. Wet-bulk density, porosity, grain density, and water content data were calculated from the nearly continuous gamma-ray attenuation porosity evaluator (GRAPE) measurements by an incorporated computer program (Boyce 1976). The data obtained were cross-checked with standard laboratory determinations of wet-bulk density. There is little deviation between the two methods (unpubl. shipboard data). Compressional-wave velocity was determined using a newly developed $p$-wave logger. Because the data determined by the $p$-wave logger are often highly affected by core fracturing (biscuiting) caused by drilling, only a few continuously mea-

\footnotetext{
${ }^{1}$ Cochran, J. R., Stow, D.A.V., et al., 1990. Proc. ODP. Sci. Results, 116: College Station. TX (Ocean Drilling Program).

2 Department of Geology. University of Nottingham. Nottingham NG7 2RD, United Kingdom.

${ }^{3}$ Present address: Department of Geology. The University. Southampton S09 5NH. United Kingdom.

${ }^{4}$ Institut für Geologie and Palaontologie, Universität Tübingen, 7400 Tübingen I. Federal Republic of Germany.

Present address: Geologisch-Paläontologisches Institut, Bernoullistrasse 32. $\mathrm{CH} 4056$ Basel, Switzerland.
}

sured sections could be used in this study. Volume magnetic susceptibility measurements were made at $5-\mathrm{cm}$ spacings on whole, unsplit sections of core using the shipboard Bartington Instruments model BS-1 magnetic susceptibility meter with 80 -mm sensing loop. Samples were taken for sedimentological analyses, including grain-size determination using an automated laser counter, and for standard compositional studies (e.g., Carver 1971).

\section{BED THICKNESS AND "STRUCTURES"}

One of the key attributes of Facies 7 is a general lack of sedimentary structures, apart from weak grading and intense bioturbation. This section, therefore, outlines the general nature of the facies and the variations observed in what is really a spectrum of characteristics (Figs. 2, 3).

At one end of the spectrum there are the true mud and silt-mud turbidites, from very thick to thin bedded, normally graded, and with the fine-grained turbidite structures (E1-E3, T5-T8) described by Stow and Piper (1984). Bioturbation may be completely absent or may extend $5-15 \mathrm{~cm}$ downward from the top of individual beds. At the other end of the spectrum are the true hemipelagites, thin-bedded, thoroughly bioturbated, palecolored muds and calcareous muds interbedded with turbidites.

Between these more readily interpreted extremes, there are thick "turbidite-like" beds of Facies 7. Typically, they are $50-100 \mathrm{~cm}$ thick with a sharp irregular base showing both erosive scours and injected mud flame structures in the same manner as the turbidites. The lowermost $5-10 \mathrm{~cm}$ is structureless, dark-colored mud or silty mud that grades upward into progressively lighter-colored and more bioturbated mud. The bioturbation is well developed even $80-90 \mathrm{~cm}$ below the top of the bed. The top is typically overlain sharply by a bed of the same kind or by a normal mud/silt turbidite.

Facies 7 beds vary in thickness from about $10 \mathrm{~cm}$ to over $150 \mathrm{~cm}$. Although the thinner beds appear similar to the thicker ones in terms of their distinctive dark to light color grading and intense bioturbation throughout, it is not really possible to distinguish them from a normal thin mud turbidite that has been extensively burrowed from the top downward after deposition. There are also thick beds where the bioturbation has extended $20,30,40$, or $50 \mathrm{~cm}$ down from the top and in which a few centimeter-thick zones of parallel lamination may be present at the base. In some cases, normal 


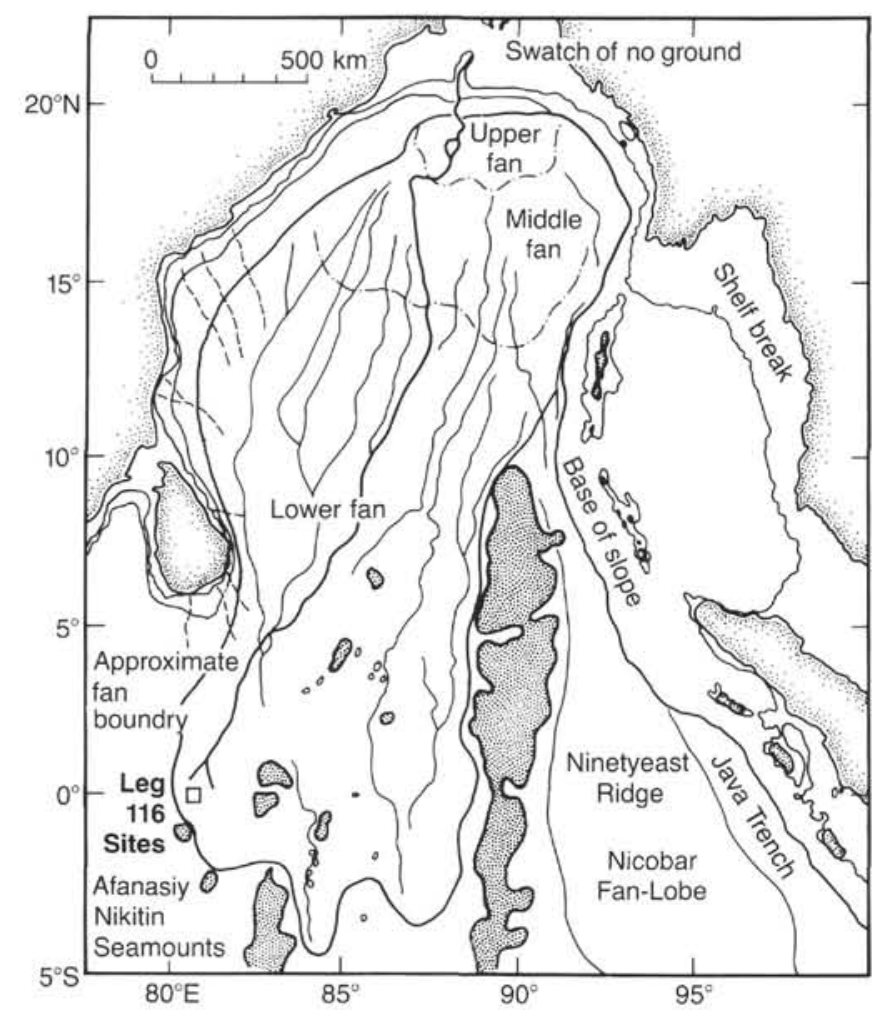

Figure 1. Site location map, distal Bengal Fan, central Indian Ocean. Base map from Emmel and Curray (1984). Fine stippled pattern denotes bathymetric highs and seamounts.

medium and thick-bedded mud turbidites grade upward into a medium to thick bioturbated zone of Facies 7. Other core sections exist in which the individual beds are less clearly defined. These sections make up about $10 \%-20 \%$ of the Facies 7 recorded. There is simply an alternation, on a scale of decimeters to a meter or so, of darker, slightly siltier, and more pale finer-grained muds. There are no sharp bed boundaries, and bioturbation extends throughout. An individual dark to light-colored cycle, with or without a sharp base, is referred to here as a depositional unit.

X-rays taken of thin slabs of core show, on a fine scale, a random homogenized mud fabric for Facies 7 (Fig. 3). The image on these X-rays is somewhat complicated by the intensive "biscuiting" of the core due to rotary drilling as well as widespread early diagenetic formation of iron sulfides (Stow et al., this volume). The overall characteristics of Facies 7 sediments can best be interpreted in terms of the initial input of material to an area, in many cases in very large quantities, by a turbidity current, and the very slow settling out of that material to allow for more or less continuous bioturbation. The nature of the beds are intermediate between those of associated turbidites and pelagites, with a spectrum of characteristics between the two. It might be reasonable to assume that the depositional process is an "intermediate" type.

\section{BIOGENIC SEDIMENTARY STRUCTURES}

Closer examination of the nature of bioturbation and the types of trace fossils in Facies 7 was carried out at the level of ichnogenera, as only burrow cross-sections were visible in the core X-rays studied. The most commonly occurring burrows belong to the ichnogener Chondrites, Planolites, Phycosiphon, Thalassinoides, and Zoophycos (Fig. 4).
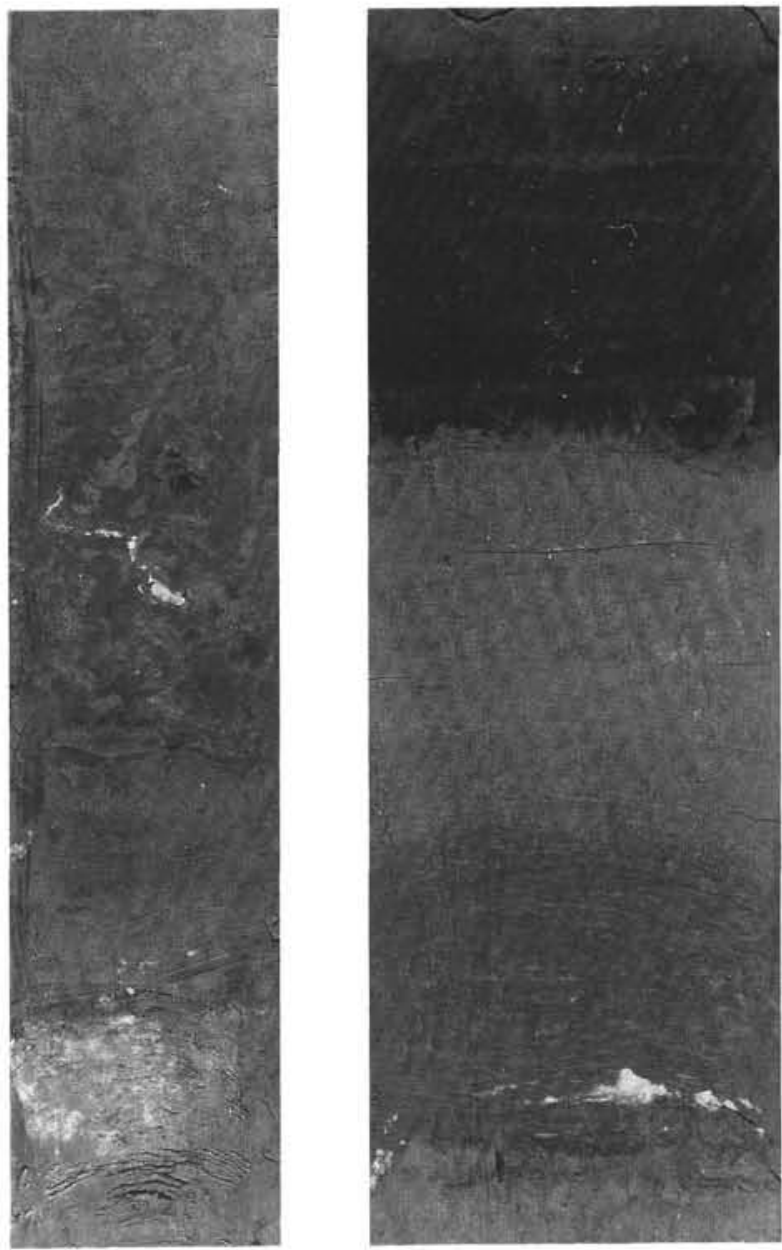

Figure 2. Core photographs showing typical examples of Facies 7 "hemiturbidites."

In general, a certain vertical sucession of biogenic structures can be deduced from the penetration depth and relative age of the burrows that can be derived from their cross-cutting relationships (e.g., Wetzel 1981, 1984; Bromley and Ekdale 1986: Savrda and Bottjer 1986). The deeper an organism burrows into the sediment, the higher is its potential to cross-cut previously dug biogenic traces. Most commonly, the penetrated burrows were more shallowly dug than the intersecting ones. Traces cross-cutting each other have nearly the same penetration depth and hence they define a certain depth level within the bioturbated zone, a so-called tier. In this way, five tiers were distinguished in the Bengal Fan sediments (Fig. 5):

1. An uppermost homogeneous layer resulting from surface-grazing organisms (often less than $1 \mathrm{~cm}$ in thickness);

2. Phycosiphon $(<5-10 \mathrm{~cm})$;

3. Planolites $(<10 \mathrm{~cm})$;

4. Chondrites $(<15 \mathrm{~cm})$; and

5. Zoophycos $(<20 \mathrm{~cm})$.

This sequence of tiers represents the steady-state depositional conditions that produced the upper part of a depositional unit (Fig. 5). This pattern is similar to that found in modern deep-sea surface sediments (Berger et al. 1979, Wetzel, 1981). A second pattern is found in the lower part of a despositional unit and differs markedly from the first one in that the sequence of tiers is out of order. In this case, a thin 
TURBIDITE

(dark grey)

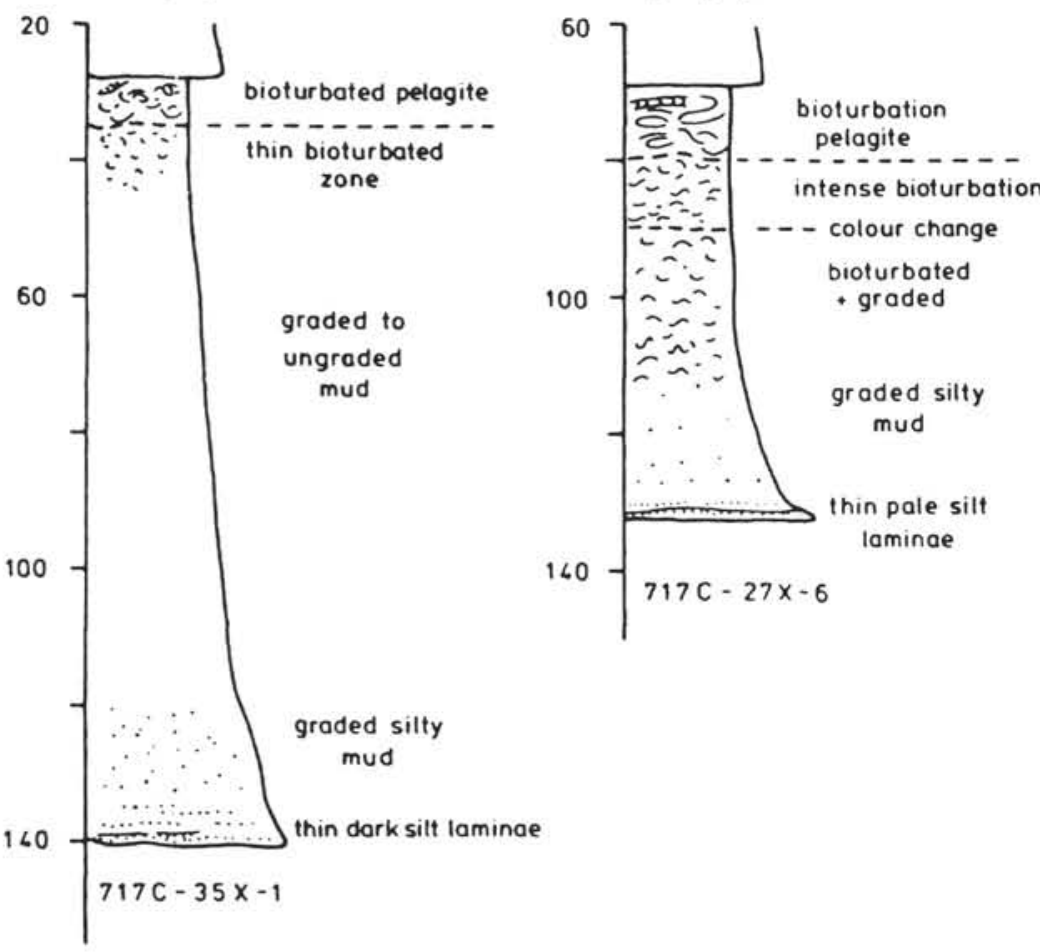

HEMITUBIDITES

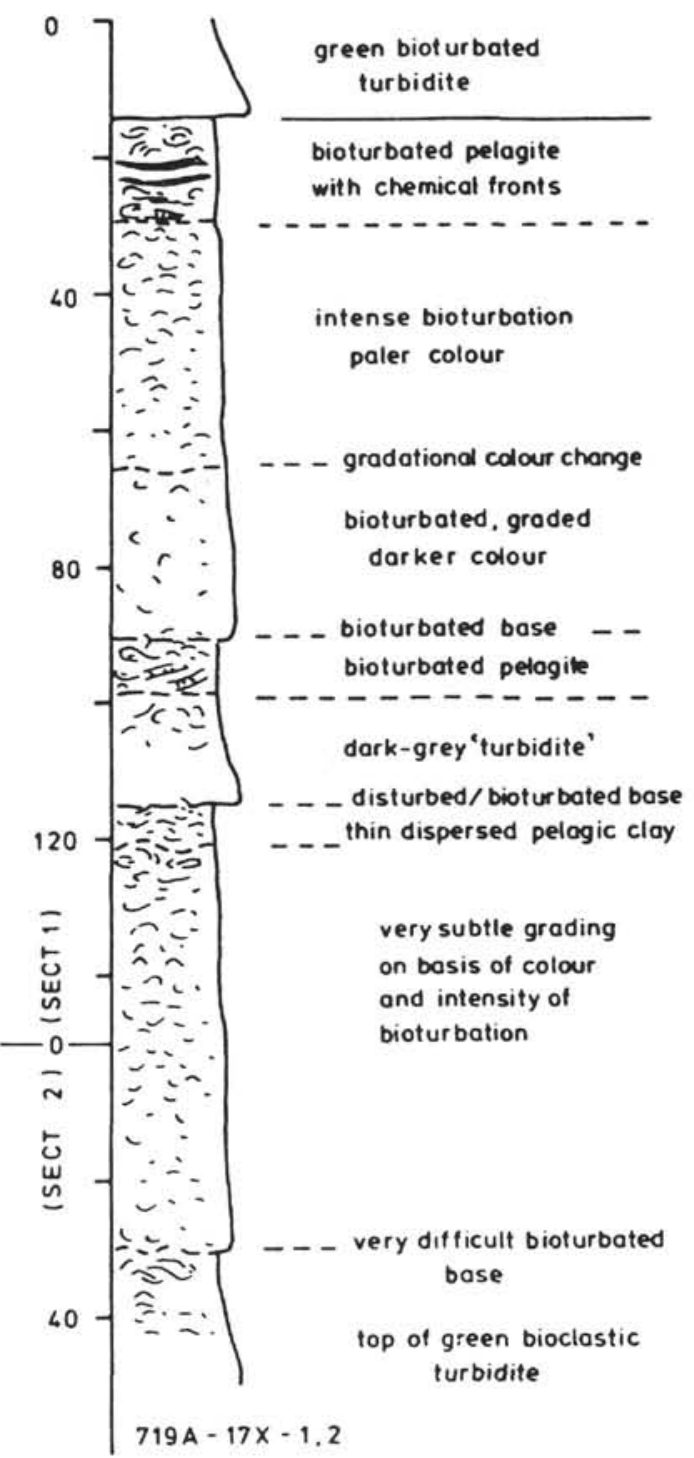

Figure 3. Sketch sections of cores showing a range of features for normal mud turbidites, Facies 7 "hemiturbidites," and pelagites.

structureless or faintly laminated basal section is overlain directly by tier 1 or tier 2 (Fig. 6). Higher within the unit, the normal tiering structure (tier 5 to 1 ) is observed, and the topmost tier 1 is preserved below the base of the succeeding unit. The lack of a sharp boundary between the lower section containing Phycosiphon (tier 2) and the normal tiering structure (often with Phycosiphon penetrated by other burrowing traces) indicates that the bioturbation was a continuous process.

This pattern of biogenic sedimentary structures can be best interpreted when considering the ecologic factors that disturb a tiered zonation of animals. Under steady-state conditions, the upper tiers are normally overprinted by the succeeding deeper tiers as the bioturbated zone moves upward due to sedimentation. Therefore, the preservation of a shallow tier (tier 2 in this case) is due to a reduction of the burrowing activity in the lower tiers. Thus, to evaluate which environmental change is responsible for such a disturbance of the "normal" tiered bioturbation pattern, the animal distribution within the seafloor needs to be considered.
The deep-sea infaunal organisms are patchily distributed on and within the seafloor (Jumars and Ekman 1983). Therefore, a certain time interval is required for the sediments within a particular area to become evenly bioturbated by a certain ichnogenus. Furthermore, the deeper that the animals are living within the deposits, the less dense is their population (Thiel, 1975, 1983), and hence the time required for significant bioturbation within a specific deeper tier increases with the penetration depth of the burrowing organisms. Because the population density of animals decreases nearly exponentially, the time required for bioturbation increases inversely with the population density.

The application of this scheme can explain the observed patterns in Facies 7 sediments. With increasing sedimentation rate, bioturbation becomes less intense to absent, first in the deepest tier where the animal density is lowest, and then successively in the shallower tiers. Consequently, the preservation of the shallow Phycosiphon tier near the base of a unit can be ascribed to temporary increase in the rate of sedimentation. Once the rate has again slowed down, then the normal 

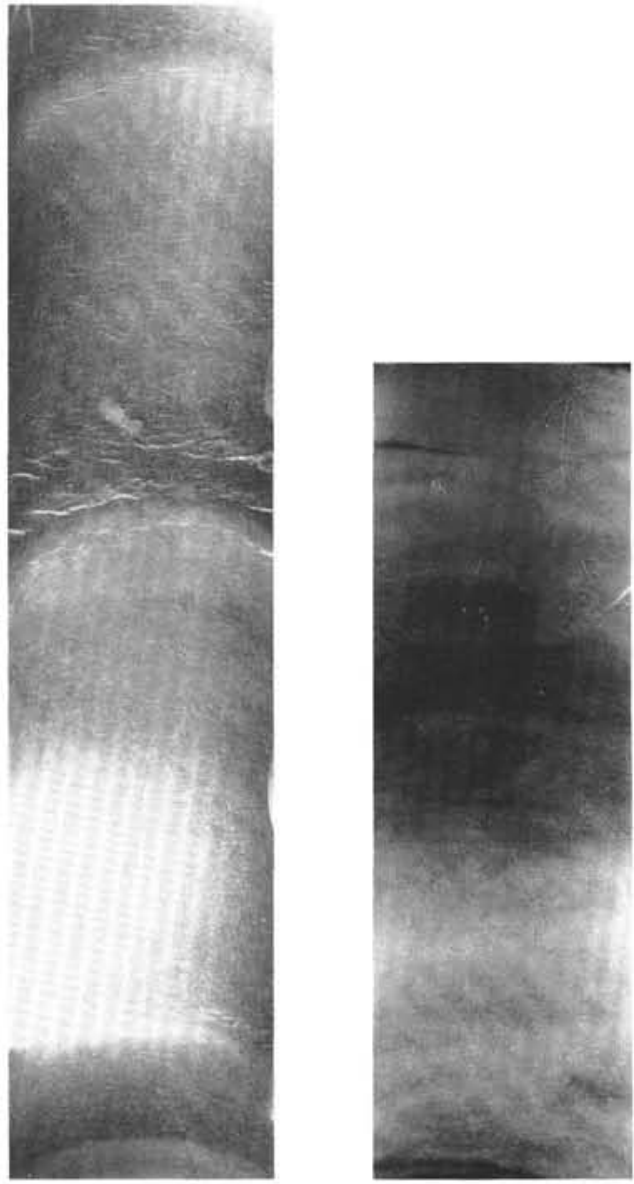

Figure 4. X-ray prints showing internal structure and fabric of Facies 7 "hemiturbidites."

tiering structure is re-established, corresponding to the upper parts of the depositional units.

We suggest, therefore, that variation in the rate of sedimentation can best account for the observed arrangement of biogenic sedimentary structures in Facies 7. We see no evidence for the possible influence on infauna of other environmental changes such as bottom-water oxygenation, sediment nutrient content, or marked variations in grain size.

\section{GRAIN-SIZE CHARACTERISTICS}

Shipboard optical examination of smear slides from Facies 7 reveals its very fine-grained clay and silty-clay grain-size characteristics. Although color gradation is evident through individual beds, size grading was not detected via optical means. Subsequent laboratory analyses confirmed the very fine, uniform grain size-all samples have a mean grain size between 7.5 and 7.9 phi with moderate sorting values $(0.75$ to $0.85)$ and symmetrical to slight positive skewness $(-0.03$ to +0.15 ). Selected smoothed frequency curves are shown in Figure 7.

Very slight positive grading through the main upper part of a depositional unit is noted in each of the beds analysed serially. The change in mean grain size is never more than 0.5 phi through this part, although where the basal few centimeters of a unit is structureless to laminated mud the mean size can be 1.0-1.5 phi greater than in the overlying bioturbated section.

These grain-size characteristics can be interpreted as representing the very finest material transported to the area by turbidity currents. Facies 7 beds certainly have the finest mean sizes of all the sediments encountered, and the sorting is better than some of the more silty muds as might be expected by the progressive prior removal of the coarser particles. The normal grading, however slight, does suggest deposition from a single "coherent" suspension.

\section{GEOTECHNICAL PROPERTIES}

\section{Wet-bulk Density}

The observed depositional units show a clear grading in wet-bulk density. At the base of a unit the highest values occur; further up, there is a continuous decrease in wet-bulk density, in some cases reaching a constant value at the top of a unit (Fig. 8). The base of a unit is mostly sharply defined on the basis of GRAPE data (for about $80 \%-90 \%$ of the observed cases), but also some transitional zones are found. The visually observed boundaries between depositional units correspond to those derived from GRAPE measurements. The sharp bases are related to well-defined, silty layers, whereas the transitional zones to be more disturbed by bioturbation. Depositional units with silt-sized sediments at the base show a difference in wet-bulk density often larger than 0.2 between top and base (in the present state of compaction). In contrast, units without a visually observable silt layer at the base show a lower difference in the wet-bulk density between top and base.

The grading in wet-bulk density is ascribed to a grading in grain size of single grains as well as aggregates. The relation between wet-bulk density and grain size of terrigeneous components is derived from the fact that the coarser the grain size, the smaller is the pore volume formed during deposition (e.g., Meade, 1966; Fuchtbauer and Muller, 1977; Bryant et al., 1981). Porosity and wet-bulk density are inversely related to each other when the grain density varies only within a small range, which is the case in the studied sediments (shipboard data: $\mathrm{s}=2.65-2.85 \mathrm{~g} / \mathrm{cm}^{3}$ ). Consequently, a grading in wet-bulk density implies a grading in grain size. A correlation between wet-bulk density and grading of grain size was proven by Einsele and Kelts (1982) for fine-grained turbidites in the Gulf of California.

The same is valid for clay aggregates; the precompacted, more dense ones are deposited first (at the base) and they form a smaller pore volume than the loosely packed aggregates that accumulated subsequently.

\section{Sonic Velocity}

Sonic velocity determinations (by $p$-wave logging as well as point measurements) also reveal a grading within the studied depositional units (Fig. 9). This can be expected from the wet-bulk density data because compressional-wave velocity and wet-bulk density are inversely related to each other if grain density is constant (e.g., Hamilton, 1974). In the studied cases the grain density varies between 2.65 and $2.85 \mathrm{~g} / \mathrm{cm}^{3}$ (shipboard data). The variation in grain density is also indicated by the different rates of decrease in sonic velocity and wet-bulk density up-section within the same depositional unit (Fig. 9), although the relationship between sonic velocity and bulk density is not necessarily linear.

At the base of the depositional units an anisotropy within bedding was typically observed, whereas in the upper part of the units the sediments behave isotropically within bedding.

The anisotropy within bedding is interpreted in the same way as for turbidite sequences studied in the Mississippi Fan (Wetzel 1987); an anisotropy within bedding results from current influence during deposition, orienting grains or aggregates with their long axes parallel to the current direction. In 

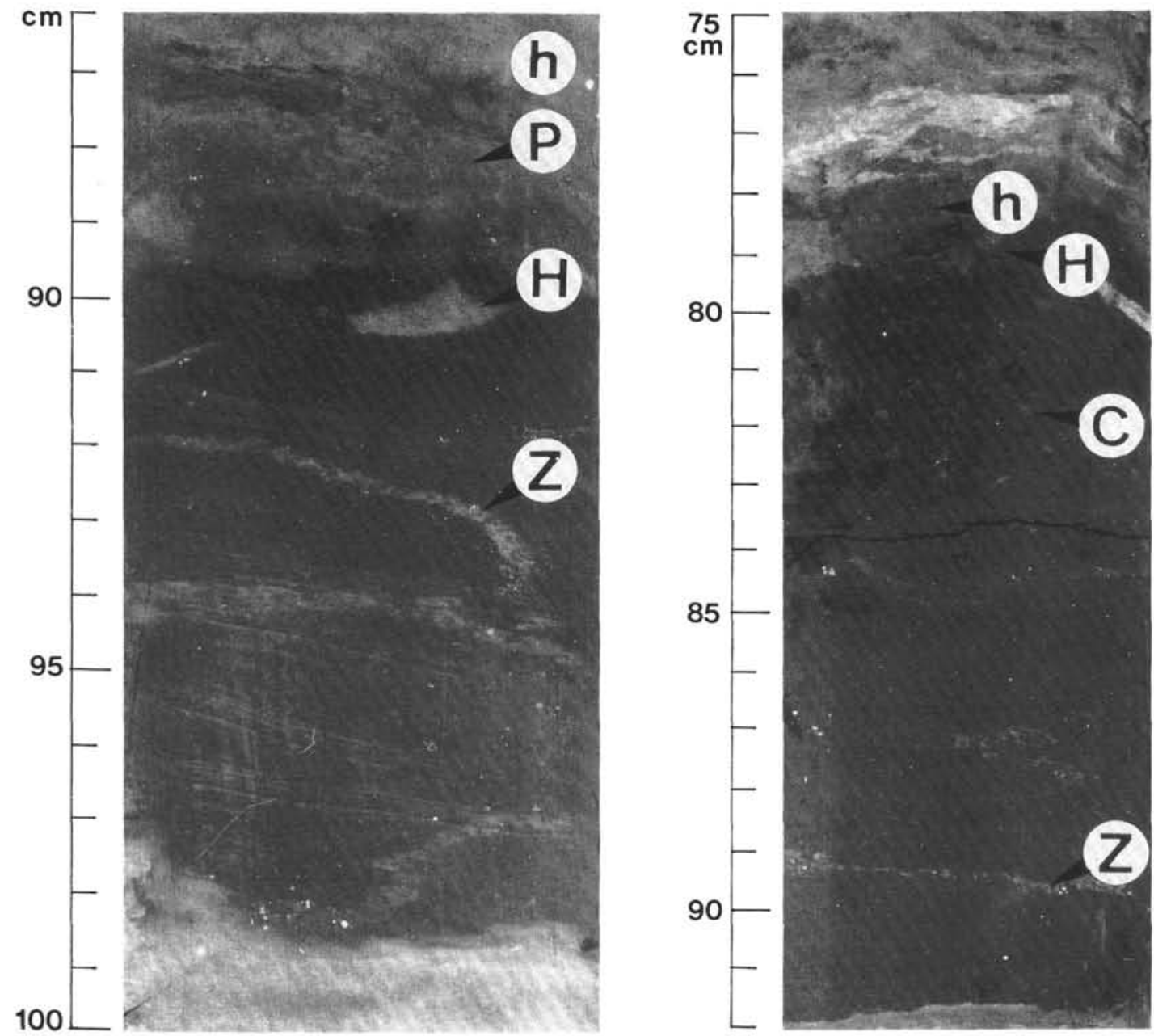

Figure 5. Commonly occurring burrows in Facies 7 "hemiturbidites." Chondrites (C), a dendroidical-branching tube system, Planolites $(\mathrm{H})$, a simple stuffed tube Phycosiphon $(\mathrm{P})$, small antler-like spreiten system, and Zoophycos (Z), a helicoidal spreiten structure. Deposits homogenized in the near-surface layer are marked with (h). Note cross-cutting relationships: Zoophycos (Z) penetrates all other traces; i.e., it is the deepest burrowing one; Chrondrites (C), Planolites $(\mathrm{H})$, and Phycosiphon $(\mathrm{P})$ show decreasing penetration depth. Below the base of the next depositional cycle (indicated by color change), a small section of homogeneous sediment (h) is often observed. Example from Leg 116 , Hole 719A: On the left, Sample 116-719A-18X-4, 86.5-100 cm; on the right, Sample 116-719A-17X-3, 75-92 cm.

contrast, the lack of anisotropy within bedding indicates deposition unaffected by currents.

For the studied depositional units the observed sonic velocity anisotropy pattern within bedding indicates that marked current influence during deposition was restricted to the lowermost part of the units. In contrast, the main portion of most units accumulated under such quiet conditions that the fabric of the fine-grained particles does not show a preferred orientation detectable by sonic measurements. As most of the units are bioturbated, the acoustic isotropy within bedding could be ascribed to biogenic reworking. However, we have also observed unbioturbated, acoustically isotropic parts of depositional units (Fig. 9).

\section{COMPOSITION AND MAGNETIC SUSCEPTIBILITY}

The interesting aspect of Facies 7 sediments with regard to composition is the variation observed between the lighter and the darker gray units. In both cases, the bulk of the components are terrigenous and most of these are clay minerals. However, the lighter gray muds have a more varied suite of clays, including chlorite, illite and smectite, and a silt-sized suite of quartz and micas together with rare heavy minerals and (?) detrital carbonate. The darker gray muds are dominated by smectite clays with some kaolinite, together with a much higher content of organic carbon, nannofossils, and early authigenic iron sulfides. Where darker gray muds grade upward into lighter gray, this is reflected in a corresponding compositional change.

These two distinct compositional types correspond closely to the light gray and dark gray turbidite muds, respectively (Facies 2 and 3 of Stow et al., this volume). The hemipelagic/ pelagic intervals (Facies 5) have a similar composition to the lighter gray muds but with rather less silt-sized material. It therefore seems most appropriate to interpret the material for Facies 7 to have been derived in some cases from the same source as for the light gray turbidites or background pelagic muds, and in other cases from the same source as the dark gray turbidites.

The nature and content of magnetic minerals in most of the sediments at the sites cored give relatively high values for both remanent magnetic intensity and magnetic susceptibility, compared with most deep-sea sediments (see Site Chapters, 


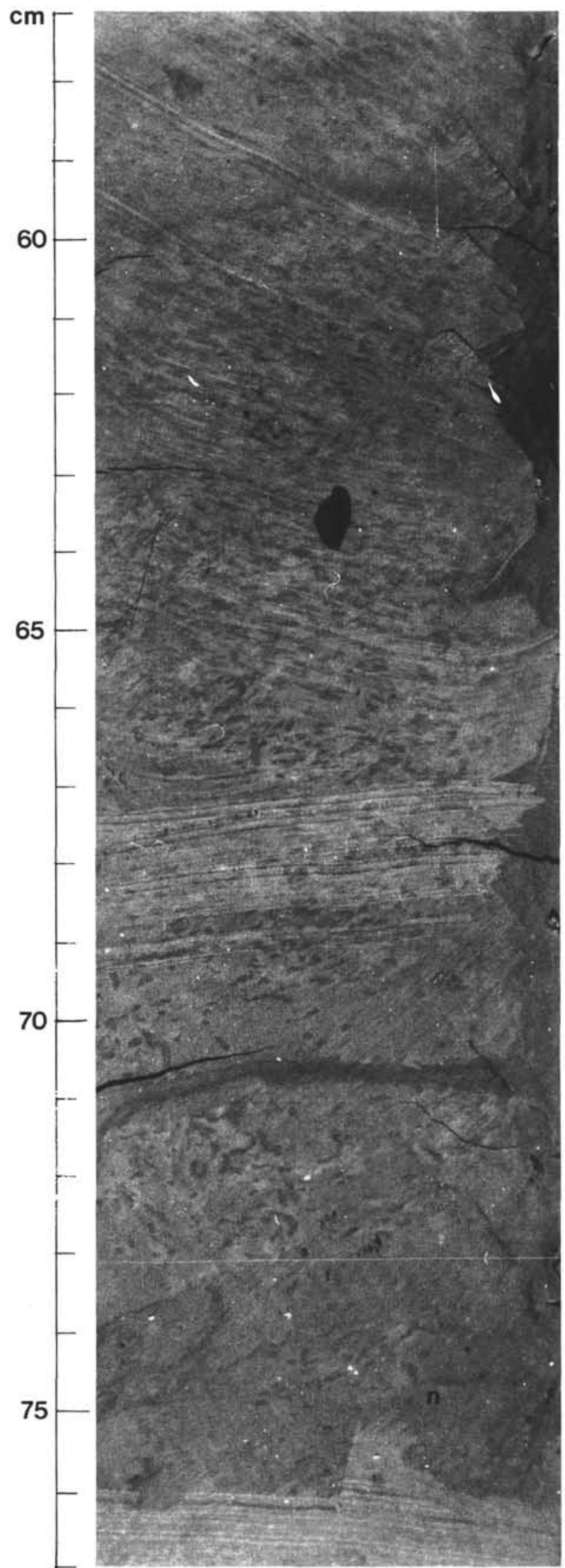

Figure 6. A core section bioturbated by Phycosiphon exceeding its penetration depth. This implies that the bioturbation was nearly simultaneous with sediment accumulation, and accumulation and biogenic reworking were in equilibrium. Core 116-717C-26X-6, 57-75 $\mathrm{cm}$ (for explanation see text).

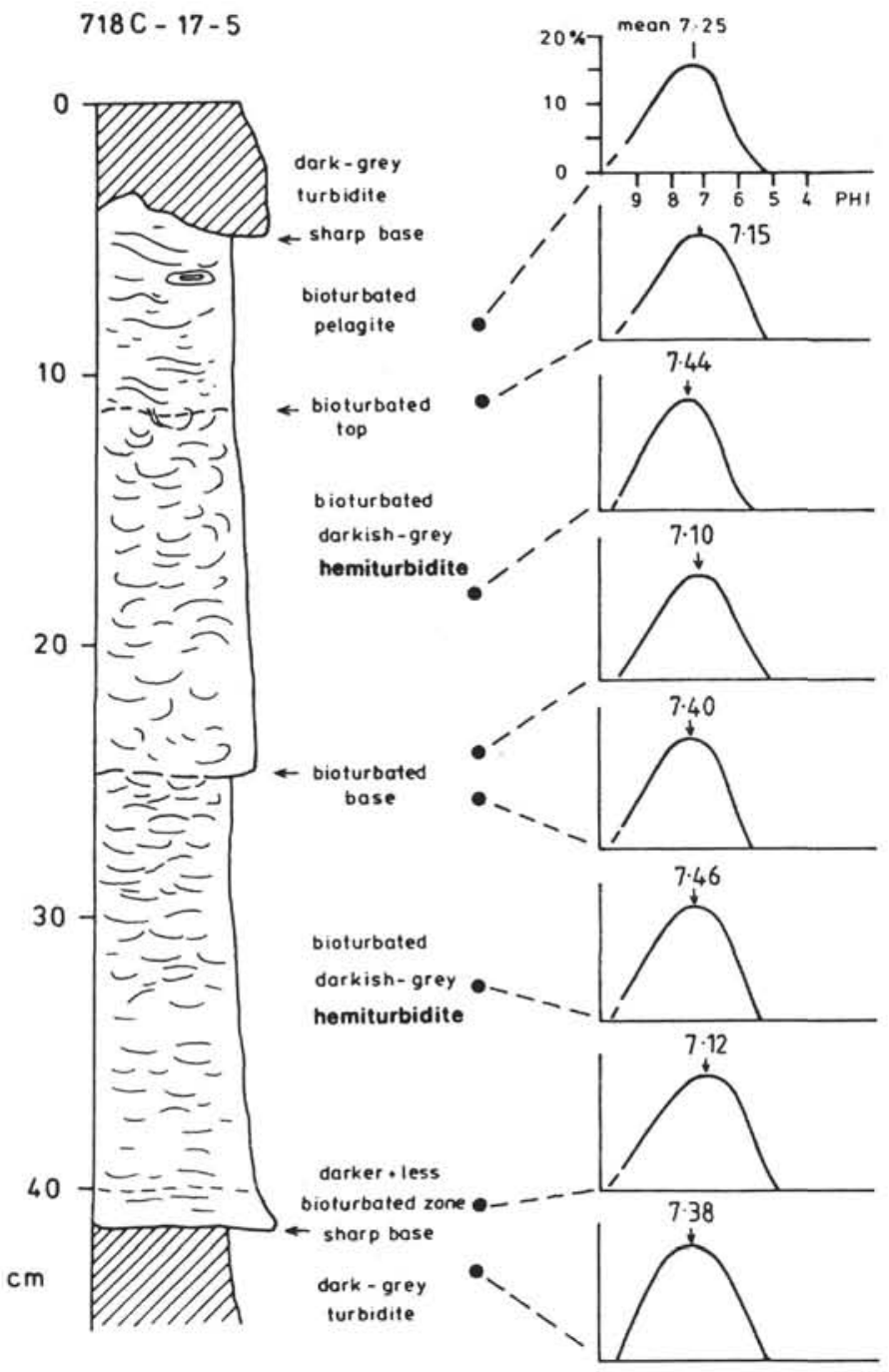

Figure 7. Selected smoothed grain-size frequency curves for Facies 7 "hemiturbidites."

Cochran, Stow, et al., 1989). Against this background, the measurements on Facies 7 sediments show relatively low values, typically $<5 \times 10^{-6} \mathrm{cgs}$ (intensity) and $<20 \times 10^{-6} \mathrm{cgs}$ (susceptibility). Where individual units are distinctly graded from dark to light gray, there are typically higher magnetic values associated with the basal darker parts of the unit-up to $10 \times 10^{-6} \mathrm{cgs}$ (intensity) and $70 \times 10^{-6} \mathrm{cgs}$ (susceptibility). These grade upward to the lower values cited above. The origin of these magnetic properties for the dark gray mud turbidites (Facies 3 ) is discussed by Sager and Hall (this volume).

\section{DISCUSSION}

\section{Depositional Process}

The sediments described in this paper and referred to as Facies 7 after Stow et al. (this volume) account for a relatively small $(<5 \%)$ but distinctive part of the succession at each of the three sites drilled on the distal Bengal Fan. They occur in association with dominant silt, mud, and bioclastic turbidites and interbedded pelagic/hemipelagic intervals. In many respects they appear transitional between the fine mud turbidites and pelagic clays. We summarize here the main characteristics that allow us to infer their probable process of deposition. 

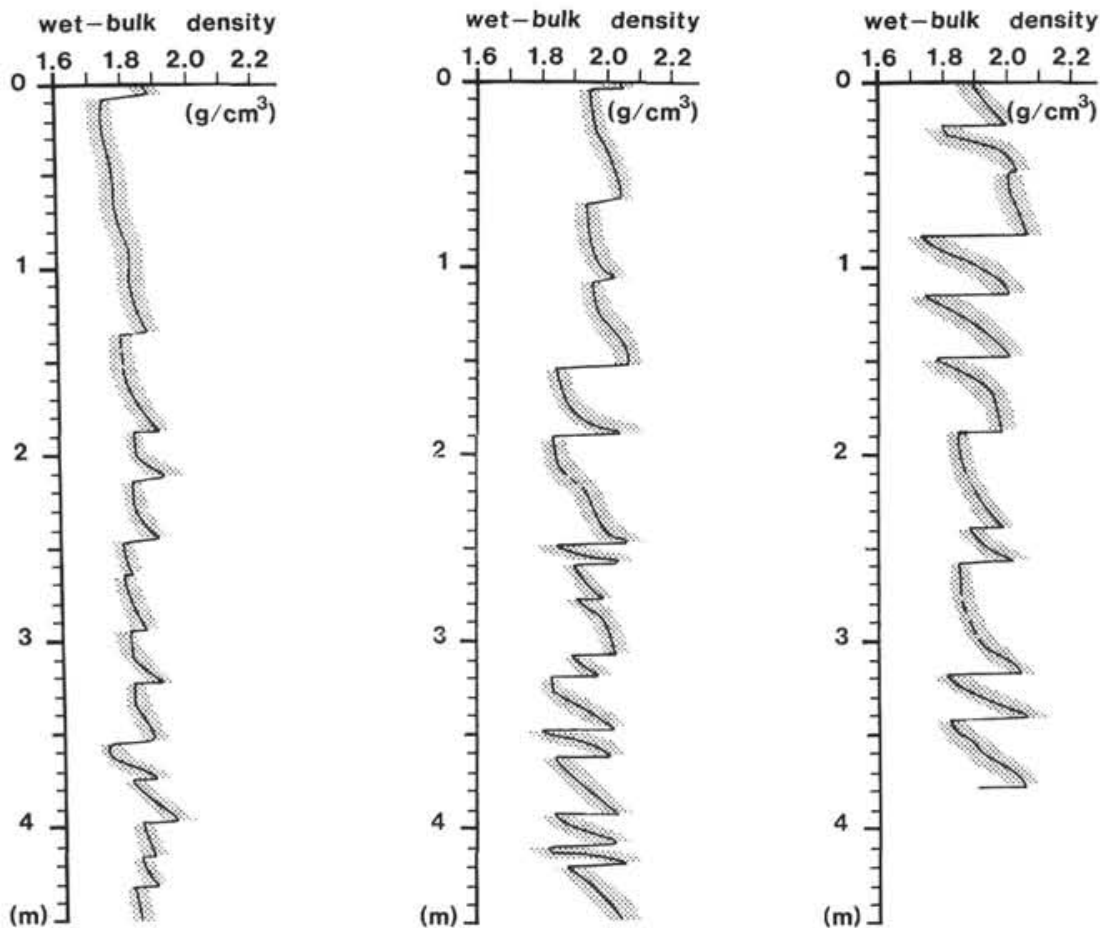

Figure 8. Variations of wet-bulk density through Facies 7 depositional units: Example from Section 116-719A-16X-4, $6 \mathrm{~cm}$ (left); Section 116-719A-36X-3, $5 \mathrm{~cm}$ (middle); and Section 116-719A-37X-4, $6 \mathrm{~cm}$ (right). Dotted areas correspond to possible measurement errors. Because wet-bulk density is related to grain size for similarly compacted deposits, grading of wet-bulk density indicates a grading of grain size. Sharp bases correspond to silt layers. Note different types of grading.

1. Structures. There are two parts to most beds: (a) a thin lower unit with a sharp base and turbidite structures, which we interpret as being deposited from a dilute turbidity current: and (b) a thick upper unit that is bioturbated throughout and color-graded, which we interpret as being deposited very slowly from a more or less stationary suspension cloud. In the absence of the distinct basal layer, the unit is the result soley of deposition from a very dilute suspension cloud.

2. Bioturbation. There has been more or less continuous bioturbation throughout deposition indicating a sedimentation rate sufficiently slow to prevent major disturbance to the infauna most of the time. Periodic and short-lived disruption of the tiering order occurs, indicating temporary increase in sedimentation rates associated with an influx of material in a low-concentration turbidity current. Normal conditions, however, are soon restored. The depth of bioturbation below the top of individual units is too great to be explained simply by downward burrowing from the top of a turbidite, but must have been due to continuous burrowing during the slower accumulation from a suspension cloud.

3. Grain size. Only the very finest sediment is present, indicating that the beds represent the last material to be deposited as the result of influx from a turbidity current. The very slight normal grading suggests deposition under the influence of gravity from a discrete suspension cloud.

4. Geotechnical properties. The changes in bulk density reflect subtle changes in grain size through depositional units. The upward decrease in bulk density in the lower part of a unit is ascribed to deposition from a moving turbidity current, whereas the near-constant bulk density over most of the bed reflects deposition from a stationary suspension cloud. The

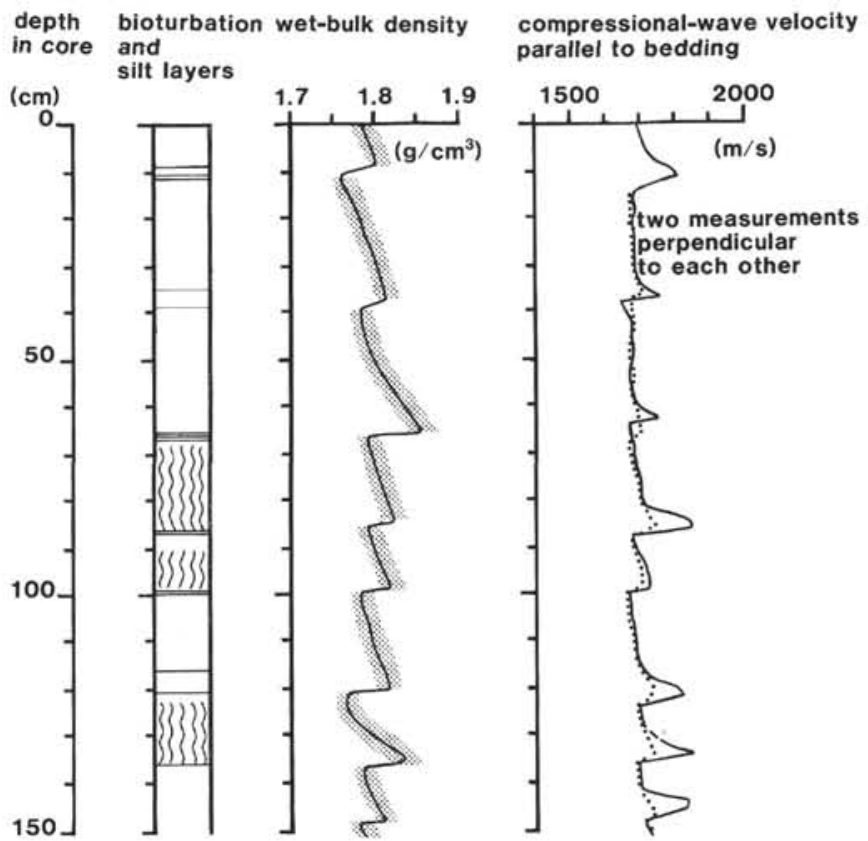

Figure 9. Correspondence between compressional-wave velocity, wet-bulk density, and visually observed silt layers and bioturbation in Section 116-719A-18X-4. Jumps in physical properties correspond to the bases of depositional units. Solid and dotted lines refer to two measurements, perpendicular to each other, of compressional-wave velocity parallel to bedding. Anisotropy is restricted to the lower part of the depositional units. 
variation from a distinct basal anisotropy of sonic velocity to an isotropic character within bedding is interpreted as evidence of current shear near the base of the bed, but no shear during deposition of the upper part.

5. Composition. From the compositional characteristics it appears that both the light gray and dark gray muddy turbidity currents have given rise to deposition from essentially stationary suspension clouds on the distal Bengal Fan. This does not appear to have happened in the case of the greenish coloured bioclastic turbidites, a fact that perhaps reflects the relatively closer source of the latter and their correspondingly more proximal aspect in the study area.

The process we envisage, then, is neither particularly new (e.g., Stanley 1983) nor unusual. Indeed, it is the logical extension of deposition from a turbidity current at its extreme distal end. It is clear that a turbidity current, having traveled over $2500 \mathrm{~km}$ and having deposited mud turbidites in excess of $2.5 \mathrm{~m}$ thick on extremely low gradients, will eventually die out. We suggest that during those dying gasps the turbidity current has become extremely dilute and simply discharges its remaining suspension of the very finest particules into the water column, perhaps up to hundreds or more than a thousand meters above the ocean floor. Further material is added to this suspension cloud as the tail of the turbidity current arrives in the area over a period of, perhaps, a few days to a week or more. Material from this cloud then settles slowly to the seafloor both above the distal feather edge of the muddy turbidite deposited from the original current, as well as beyond the point that the true turbidite has reached. Sedimentation is sufficiently slow that bioturbation continues throughout. This concept is illustrated in Figure 10.

The process of forming a thick dilute suspension cloud at the most distal part of a turbidity current's flow path may be enhanced by a marked change in gradient or by topographic ponding of the flow. There appears to be no possibility of ponding on this part of the distal Bengal Fan. However, there is slight surface expression of the deforming ocean crust and sediment pile in the central Indian Ocean, although the regional bathymetry is very poorly constrained. A distinct, east to west-trending, buried ridge lies between Sites 719 and 718. A similar ridge just south of Site 719 does appear to have some positive relief at the seafloor, possibly a few tens of meters. Either of these may have presented a significantly greater barrier to southward flowing turbidity currents in the past and so have resulted in the development of more substantial and/or more common suspension clouds in the area.

\section{Time Estimates}

Our knowledge of depositional rates for individual beds in turbidite environments is not good. Recent estimates summarized by Stow and Piper (1984) suggest a few days to a week or more for deposition of a thick mud turbidite. Sedimentation of the depositional units from suspension clouds would, clearly, take longer.

We can make an estimate of the approximate time scale involved from the bioturbation pattern observed, provided that:

1. The lower part of a depositional unit is continuously bioturbated by a trace " $\mathrm{A}$ " belonging to an upper tier;

2. The thickness of the depositional unit considerably exceeds the penetration depth of ichnogenus "A"';

3. The penetration depth of the trace " $A$ " tier can be determined; and

4. The bioturbation rate of the organism producing " $\mathrm{A}$ " is known.

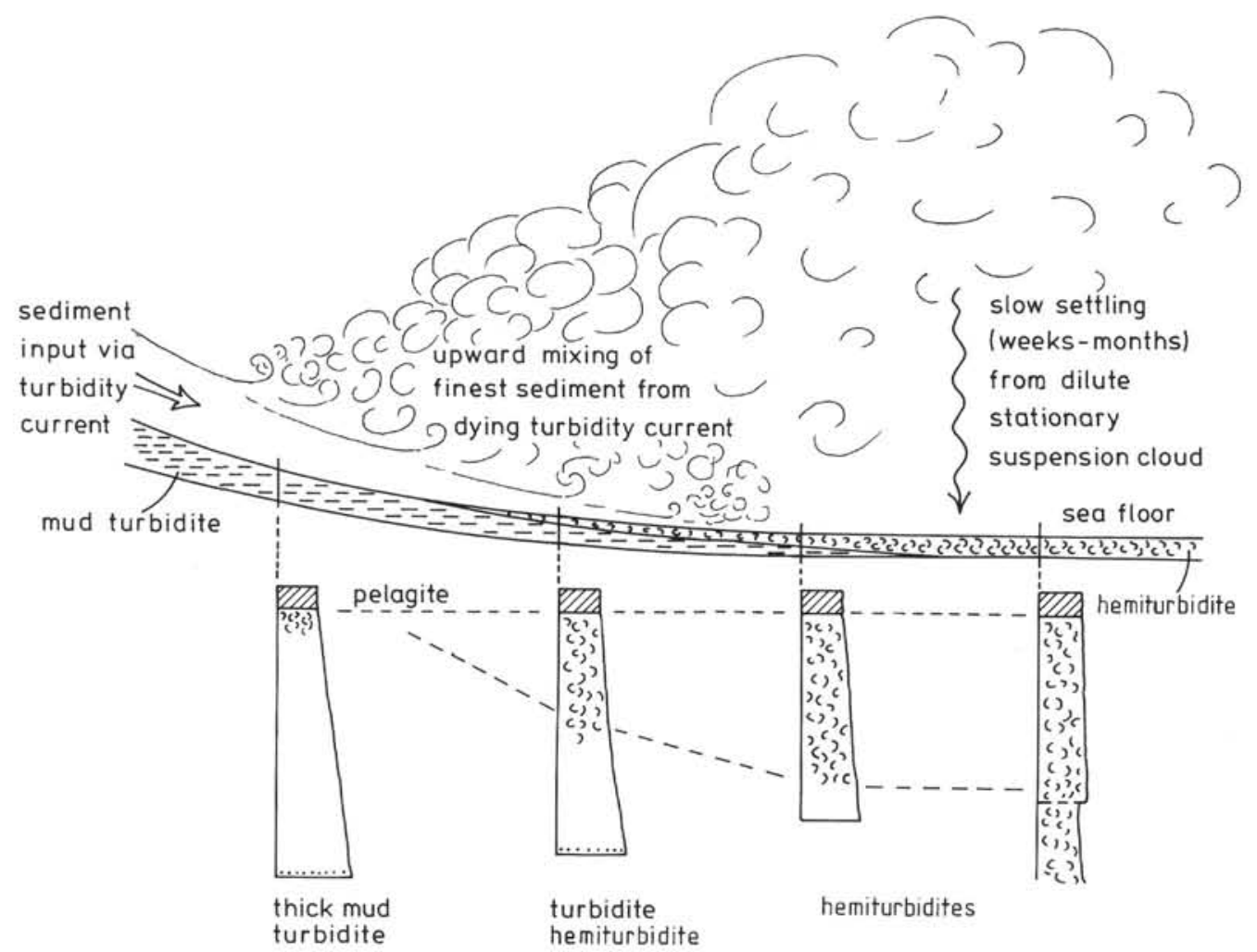

Figure 10. Schmatic diagram illustrating the inferred depositional process for "hemiturbidites." 
If these parameters are known, the sedimentation time can be estimated from the following formula:

$$
T=\frac{d-d_{p}}{r A}
$$

Where

$$
\begin{aligned}
& T=\text { time for sedimentation (hours) trace } \\
& d=\text { thickness of depositional unit bioturbated by trace } A \\
& \mathrm{~m}) \\
& d_{p}=\text { normal penetration depth of trace } A(\mathrm{~cm}) \\
& r A=\text { rate of sediment reworking by trace } A(\mathrm{~cm} / \mathrm{hr}) .
\end{aligned}
$$$$
\text { (cm) }
$$

For these conditions to hold, sedimentation and bioturbation must be in equilibrium during the time that is represented by the lowest part of the depositional unit that is bioturbated, and the distance from this lowest part to the normally tiered succession must be larger than the penetration depth of the specific ichnogenus " $\mathrm{A}$ ". This part can only be bioturbated when sediment accumulation has not exceeded sediment reworking by organisms. Consequently, the organisms producing the trace " $\mathrm{A}$ " must have lived (pene-) contemporaneously with the accumulation of the depositional unit.

These conditions are fulfilled in the studied depositional cycles of the outer Bengal Fan. Items 1 and 2 are self-evident. Item 3, the penetration depth of Phycosiphon is, at maximum, only as deep as $10 \mathrm{~cm}$, based on observations in modern turbidite sequences from the Sulu Sea (Wetzel 1983), but in the studied sediments it is on the order of $1-5 \mathrm{~cm}$ as deduced from the preserved tiering structure below the base of the depositional units (Fig. 5). Item 4, the bioturbation rate for deep-sea organisms producing a specific ichnogenus, is unknown. Here, we must use laboratory data from Phycosiphonsized (but not producing) organisms (Howard and Elders 1970) and extrapolate the results to deep-sea conditions within a certain range of error.

The reworking of sediment by small-sized organisms is fast (Howard and Elder 1970); a layer 5 to $10 \mathrm{~cm}$ thick shows significant bioturbation produced by Phycosiphon-sized organisms within 5 to $10 \mathrm{hr}$ in an aquarium.

In the deep sea, however, the reworking may be much slower than in the laboratory because of the effects of cooler temperature and sparser nutrients that may slow down organism activity (Turekian et al. 1975). Here, we assume that the biologic activity may decrease by a factor of 2 to 10 in comparison to the rates determined by Howard and Elders (1970).

Accepting these limits, the accumulation rate of a unit containing a $15-\mathrm{cm}$ thick Phycosiphon interval below the first Zoophycos may be in the range of 0.5 to $10 \mathrm{~mm} / \mathrm{hr}$ for the lower part of the cycle. That rate range means that the accumulation of one depositional unit $1 \mathrm{~m}$ thick may have taken about 6 weeks. However, this is no more than a very rough estimation because direct measurements of bioturbation rates in deep-sea sediments are not yet available. Depending upon the extrapolation factor used, the time for sedimentation of a thick unit may range up to 6-12 months.

\section{A New Type of Deep-sea Sediment}

The facies we have described in this paper is neither a true turbidite nor a true pelagite or hemipelagite. It has distinctive, recognizable characteristics and is deposited by a process that we suggest is common at the distal end of any turbidity current pathway. Both of the terms turbidite and hemipelagite have become overused, "bucket" terms in the literature on deepwater facies (Stow, 1986; Pickering et al., 1986). Although most contourites are also continuously bioturbated (Stow and Lovell, 1979); Stow, Faugeres, et al., 1986), there is no evidence for bottom-current influence on the sediments we describe here. The unifites (or homogenites) described from the Mediterranean Basin (Stanley 1981) are not so thoroughly bioturbated and are similar in characteristics to the thick mud turbidites of abyssal (e.g., Weaver et al., 1986; Piper and Stow, 1989). The thick, structureless muds of the Mississippi Fan channel fill drilled on DSDP Leg 96 (Stow, Cremer, et al., 1986) are generally unbioturbated, although the depositional process remains enigmatic.

We propose, therefore, that the facies described here deserves a new name. Discussion aboard the JOIDES Resolution during Leg 116 ranged from the unadventurous (turbid, hemiturbid) to the more emotive (cloudite) to the absurd (quasi-semihemi-turbidite!). After much debate, we propose the term hemiturbidite, which emphasises the transitional characteristics of the sediment between turbidite and hemipelagite.

A hemiturbidite then, is defined as a fine, muddy sediment with partly turbiditic and partly hemipelagic characteristics. It occurs as a more or less distinct bed of dominantly turbiditic material within a distal turbidite environment. It shows evidence of continuous bioturbation throughout its deposition, except in some cases for a thin (generally $<5 \mathrm{~cm}$ ), structureless unit at the base. Slight normal grading is evident despite the thorough bioturbation. A hemiturbidite is deposited from an essentially stationary suspension cloud that is produced from a dying turbidity current. The lowermost unit of the deposit may represent the most distal deposit of that turbidity current.

\section{ACKNOWLEDGMENTS}

Financial support by the Deutsche Forschungsgemeinschaft is gratefully acknowledged by A. W. Secretarial and technical support was provided to D.A.V. Stow at the University of Nottingham. All the sedimentologists and other participants on board JOIDES Resolution (Leg 116) are thanked for their part in the unfolding story of hemiturbidites.

\section{REFERENCES}

Berger, W. H., Ekdale, A. A., Bryant, P. P., 1979. Selective preservation of burrows in deep-sea carbonates. Mar. Geol., 32:205230.

Boyce, E. R., 1976. I. Definitions and laboratory techniques of compressional sound velocity parameters and wet-water content, wet bulk density, and porosity parameters by gravimetric and gamma ray attenuation techniques. In Schlanger, S. O., Jackson, E. D., et al., Init. Repts. DSDP, 33: Washington (U.S. Govt. Printing Office), 931-958.

Bromley, R. G., and Ekdale, A. A. 1986. Composite ichnofabrics and tiering in burrows. Geol. Mag., 123:59-65.

Bryant, W. R., Bennett, R. H., and Katherman, C. F., 1981. Shear strength, consolidation, porosity and permeability of oceanic sediments. In Emiliani, C. (Ed), The Oceanic Lithosphere. The Sea (Vol. 7): New York (Wiley), 1555-1615.

Carver, R. E., 1971. Procedures in Sedimentary Petrology: New York (Wiley).

Cochran, J., Stow, D.A.V., et al., 1989. Proc. ODP, Init. Repts., 116: College Station, TX (Ocean Drilling Program).

Einsele, G., and Kelts, K., 1982. Pliocene and Quaternary mud turbidites in the Gulf of California: sedimentology, mass physical properties and significance. In Curray, J. R., Moore, D. G., et al., Init. Repts. DSDP, 64 (Pt. 2): 511-528.

Emmel, F. J., and Curray, J. R., 1984. The Bengal Submarine Fan: northeastern Indian Ocean. Geo-Mar. Lett., 3:119-124.

Fuchtbauer, H., and Muller, G., 1977. Sedimente und Sedimentgesteine (3rd ed). Stuttgart (Schweizerbarth). 
Hamilton, E. L.. 1974. Prediction of deep-sea sediment properties: state-of-the-art. In Inderbitzen, A. L. (Ed.), Deep-sea Sediments: Physical and Mechanical properties. Mar. Sci. (Vol. 2): New York (Plenum), 1-43.

Howard, J. D., and Elders, C. A., 1970. Burrowing patterns of haustoriid amphipods from Sapelo Island, Georgia. In Crimes, T. P., and Harpter, J. C. (Eds.), Trace Fossils. Geol. J., Spec. Issue, 3:243-262.

Jumars, P. A., and Ekman, J. E., 1983. Spatial structure within deep-sea benthic communities. In Rowe, G. T. (Ed.), Deep-Sea Biology. The Sea (Vol. 8): New York (Wiley).

Meade, R. H., 1966. Removal of water and rearrangements of particles during the compaction of clayey sediments-review. U.S. Geol. Surv. Prof. Pap., 497B.

Pickering, K. T., Stow, D.A.V., Watson, M. A., and Hiscott, R., 1986. Deep-water facies, processes and models: a review and classification for modern and ancient sediments. Earth Sci. Rev., 223:75-174.

Piper, D.J.W., and Stow, D.A.V., 1989. Fine-grained turbidites. In G. Einsele and A. Seilacher (Eds.), Cyclic and Event Stratification (2nd ed.): New York (Springer Verlag).

Savrda, C. E., and Bottjer, D. J., 1986. Trace Fossil model for reconstruction of paleo-oxygenation in bottom waters. Geology, $14: 3-6$.

Stanley, D. J., 1981. Unifites: structureless muds of gravity-flow origin in Mediterranean Basin. Geo-Mar. Lett., 1:77-84.

1983. Parallel-laminated deep-sea muds and coupled gravity flow-hemipelagic setting in the Mediterranean. Smithsonian Contrib. Mar. Sci., 19.

Stow, D.A.V., 1986. Deep Clastic Seas. In Reading, H. G. (Ed.), Sedimentary Environments and Facies: Oxford (Blackwell Sci. Publ.), 398-444.

Stow, D.A.V., and Lovell, J.P.B., 1979. Contourites: their recognition in modern and ancient sediments. Earth Sci. Rev., 14:251291

Stow, D.A.V., and Piper, D.J.W., 1984. Deep-water fine-grained sediments: facies models. In Stow, D.A.V., and Piper, D.J.W. (Eds.). Fine-grained sediments: deep-water processes and facies. Spec. Publ., Geol. Soc. London, 14:611-645.

Stow, D.A.V., Faugeres, J. C., and Gonthier, 1986. Facies distribution and drift growth during the late Quaternary, Faro Drift, Gulf of Cadiz. Mar. Geol., 72:71-100.
Stow, D.A.V., Cremer, M., Droz, L., Meyer, A. W., Normark, W. R., O'Connell, S., Pickering, K. T., Stelting, C. E., Angell, S. A., and Chaplin, C., 1986. Facies, composition and texture of Mississippi Fan sediments, Deep Sea Drilling Program Leg 96. Gulf of Mexico. In Bouma, A. H., Coleman, J., et al. (Eds.), Init. Repts. DSDP, 96:475-487.

Thiel, H., 1975. The size structure of the deep-sea benthos. Int. Rev. ges. Hydrobiol., 60:575-606.

1983. Meiobenthos and nanobenthos of the deep sea. In Rowe, G. T. (Ed.), Deep-Sea Biology. The Sea (Vol. 8): New York (Wiley), 167-230.

Turekian, K. K., Cochran, J. K., Khakar, D. P., Cerrato, R. M., Vaisnys, J. R., Sanders, H. L., Grassle, J. F., and Allen, J. A., 1975. Slow growth rate of deep-sea clam determined by ${ }^{225} \mathrm{Ra}$ chronology. Proc. Nat. Acad. Sci. (USA), 72:2829-2832.

Weaver, P.P.E., Searle, R.C., and Kuijpers, A., 1986. Turbidite deposition and the origin of the Madeira Abyssal plain. In Summerhayes C. P., Shackleton, N. J. (Eds.), North Atlantic Palaeogeography. Spec. Publ., Geol. Soc. London, 21:131-143.

Wetzel, A., 1981. Okologische und stratigraphische Bedeutung biogener Gefuge in quartaren Sedimenten am NW-afrikanischen Kontinentairand. "Meteor" Forsch.-Ergeb. C., 34:1-34.

1983. Biogenic structures in modern slope to deep-sea sediments in the Sulu Sea Basin (Philippines). Palaeogeogr., Palaeoclimatol., Palaeocol., 42:285-304.

1984. Bioturbation in deep-sea fine-grained sediments: influence of sediment texture, turbidite frequency and rates of environmental change. In Stow, D.A.V. and Piper D.J.W. (Eds.), Fine-Grained Sediments: Deep Water Processes and Facies. Spec. Publ., Geol. Soc. London, 24:595-608.

1987. Sedimentological significance of strain and sonic velocity anisotropy in fine-grained turbiditic and hemopelagic deep-sea sediments-an example from the Mississippi Fan. Mar. Geol., 74:191-207.

Date of initial receipt: 7 July 1989

Date of acceptance: 5 February 1990 Ms 116B-152 